Araştırma Makalesi / Research Article

\title{
ANTHONY GIDDENS: YAPILAŞMA KURAMI VE DİN OLGUSU ÜZERİNE BİR DEĞERLENDİRME
}

\author{
Ahmed Hamza ALPAY* \\ İhsan ÇAPCIOĞLU**
ANTHONY GIDDENS: AN ASSESSMENT ON STRUCTURATION THEORY AND PHENOMENON OF RELIGION

Öz

Dünya tasavvuru, bireyin bilincindeki akla uygunluğun -gerçeklik hakkındakikavrayışsal ihtiyaçlarında tasdik edilmektedir. İnsan ve tecrübe ettiği dünya arasındaki diyalektik süreç tarihsel düzlemde toplumsal olgu ve olaylara intibak ederek anlam kazanmaktadır. Yaşadığı toplumun katmanlarında rol ve kimliklere bağlı olarak faaliyet gösteren insan, aynı zamanda bir kültür formunun aktörü olarak ortaya çıkmaktadır. Ekonomik, hukuki, siyasal, kültürel, dini yapılanmalar insan-toplum etkileşiminin somut göstergeleri olarak konumlanmaktadırlar. Her düşünür-sosyolog yaşadığı toplumu ve dünyayı kendi anlam dünyası ve dişsal nesnelliklere bağlı olarak etkilendiği olgu ve olaylar çerçevesinde tanımlamaktadır. Bu makalede Anthony Giddens öğretisi; bilgi, toplumsal sınıftabakalaşma, eylemsel aktör olarak birey ve din sosyolojisi ekseninde ortaya konulacak ve değerlendirilecektir.

Anahtar Kelimeler: Anthony Giddens, Din, Diyalektik, Toplum, Yapılaşma Kurami.

\begin{abstract}
The imagination of the world is substantiated in the cognitive needs of convenience to the mind -about authenticity- in the consciousness of the individual. The dialectical process between human beings and the world of experience gains meaning by adapting to social phenomena and events in the historical plane. People who operate in the layers of the society, depending on roles and identities, the human being are also emerging as actors of a cultural form. Economic, legal, political, cultural, religious structures are positioned as perceptible signs of human-society interaction. Every thinker-sociologist describes the society and the world he lives in within the context of phenomenon
\end{abstract}

\footnotetext{
* Doktora Öğrencisi, Ankara Üniversitesi, SBE, Din Sosyolojisi Programı, eposta: ahmedhamza0606@outlook.com, https://orcid.org/0000-0002-8781-6939.

** Prof. Dr., Ankara Üniversitesi, İlahiyat Fakültesi, e-posta: ihsancapcioglu@yahoo.com, https://orcid.org/0000-0003-4796-5232.

Makale Gönderim Tarihi : 07.07.2019 https://doi.org/10.11616/basbed.v19i49542.588158 Makale Kabul Tarihi $\quad: 12.09 .2019$
} 
and events that are influenced by his own world of meaning and external objectivities. In this article, the doctrine of Anthony Giddens will be set forth and evaluated in the axis of knowledge, social class-stratification, the individual action as an actor and the sociology of religion.

Keywords: Anthony Giddens, Religion, Dialectical, Society, Structuration Theory.

\section{Giriş}

Bilginin tarihselliği ve nesnelliği sosyal bir olgu olmasından kaynaklanmaktadır (Yılmaz, 1996: 9). Bilginin ihtiyaç boyutu, insanların ve toplumların inşa edilmiş dünyalarında ve hayatlarında, her aşamada kendisini göstermektedir. İnsanın bilgiyi yaratan ve özümseyen yapısal konumu, hem dünyayı hem de dünyadaki olguları değiştirebilen varoluş sürecini kendi içinde anlamlı kılmaktadır. İnsanın bilgiyle olan diyalektik süreci, onun bilgi karşısında özne ya da nesne durumundaki konumlanışıdır. Bilginin algılanması, anlamlandırılması ve yorumlanması; insan ve toplum ilişkilerinin çevresel etki analizlerinde değişkenlik göstermektedir (Apalı, 2015: 190). Sosyal yapının diyalektiğinde bilginin rolü nesnelleştirim, kurumsallaştırım ve meşrulaştırım çözümlemeleri olarak sosyal eylem ve kurumlar teorisine ve din sosyolojisine doğrudan uyarlanabilmektedir (Berger ve Luckmann, 2003: 299). Drucker'e göre bilgi, günümüzdeki anlamlı tek kaynaktır. İletişim ve enformasyon tabanına dayanan olgu ve süreçler toplumsal yapıyı gittikçe daha fazla belirlemektedir. Yaşanan değişimler toplumları şekillendirmekte ve geliştirmektedir (Varol, 2010: 121-122). İnsanın sonlu içgüdüsel yeteneklerinin dişındaki toplumsallıkla bilgiyi öğrenmesi, bilmenin de toplumsalı kapsayan nitelikte bir eylem olmasinı sağlamaktadır. Bilgi merkezi olarak toplum; gerçekliği, dünyayı bilmemizi sağlayan bir olgudur. Bilmek de insan varlığını ve bu varlığın değişken koşullarını oluşturmanın temelidir (Yılmaz, 2009: 42).

Ontolojik bakış açısı ise var olanların, çeşitliliğin içinden geçen bütünleyici birlikteliğine, en üst aşamadan katkı sağlayan varoluşsal bir bakıştır. Ontoloji, mütevazi özellikteki taşıyıcı savıyla; disiplinlere ilişkin sorunları, onların varlık dayanaklarına müdahil olmadan göstermektedir. Bilgi teorisi, bilginin varlık temelini; nesnelerin değişmez alanlarındaki kavramların içeriklendirilmesinde ve deneyimlerin duyumlar yoluyla alg1 bütünleşmesindeki kavrama dayanağını-, insana özgü var olanların çeşitliliğinde, bağıntılar ve bilinmeye yönelinmiş değişmezlerde ortaya koymaktadır. Kaosun kosmos ile, sürekliliğin kesinti ile, devrimin evrim ile asimetrinin simetri ile ortaya çıkması; diyalektik bir sürecin işareti 
olan bu fenomenlerin, bilginin yeniden üretiminde sağladıkları ontolojik birliktelik çağların her döneminde görülmektedir (Nutku, 2006: 82).

Hobbes, Platon, Leibniz, Aristoteles, Smith, Marx, Hegel ve Engels ontolojik düşünce yapıları, ileri sürmüş oldukları açık tezleri ve bu tezler üzerine inşa ettikleri epistemolojik kuramlarıla bu konudaki önemli düşünürlerdendir. $\mathrm{Bu}$ bağlamda ontoloji karşıtı bakış açısıyla Locke, herhangi bir düşünce belirtmeyi açıkça reddetmiş; Hume ve Kant ise agnostik bir tavır sergileyerek konu hakkında düşünce belirtmekten kaçınmışlardır. Ontolojik soruların cevaplarını bulmak durumunda kalan her üç düşünürün de kaçınamadığı, üzerinde konuşulan olgular bulunmaktadır. Bu durumlara örnek olarak Kant, özün aynı anda hem var olduğunu hem de var olmadığını ileri sürerek (Ding-an-sich/kendindeşeyin); Locke ise düşünce dünyamızın kökeninde maddenin olup olmadığıyla ilgili düşüncesini belirtmemiş fakat nihayetinde Tanrı kavramının sonsuzluğuna vurgu yaparak göstermiştir (Göçmen, 2009: 3). Aristoteles için asıl gerçek varlık tek tek nesnelerdir (Çelebi, 2014: 77). Heidegger'e göre; Aristoteles düşüncesinde, varlığa özdeş yapıların kategorik ilkeleri düşünmeye yol açan temel özelliktedir. Nietzsche'de vücut bulan nihilizm, varlığın aşkın bir değere bağlı olmamasında, varlıkla hiçliğin anlamsal ilintisinde yer bulmaktadır. Nietzsche hiçliği, aşkın bir değer için hiçbir varlığın olmaması olarak görmektedir. Bu doğrultuda hiçbir değerde bağlılık göstermeyen aşkın varlık, hiçliğin yurdunda anlamlı bir oluş kazanmaktadır (K1lıç, 2014: 13-19).

Descartes ise yöneldiği düşüncelerinde, Tanrı'nın temsilinden ziyade kendisinin şüpheciliğindeki amaçlarıyla farklılaşan bir temsil anlayışında bulunmuştur. Böylece Descartes, kesin bir bilgi sağlamak ve imanındaki şüpheleri yok etmek için düşüncelerini delillendirmek istemiştir. Ona göre, metafizik hakikate ve kesinliğe götüren tek emin yol, açık ve seçik fikirlerin teşkili ve bunların aklen tahlil edilmesidir (Dă̆, 1979: 289). İdealist felsefeye katkılarıyla öncül konumda olan Platon, varlık dünyasını idealar dünyası ve duyular dünyası olmak üzere ikiye ayırmaktadır. Değişim ve devinimin olmadığı idealar dünyası, tek tek nesneleri özünde barındıran ve hep aynı kalan, asıl gerçekliğin olduğu dünyadır. Varoluşları kendinden olan idealar dünyası için var olmak, bir başka şeyde ihtiyaçsız olmaktır. Felsefeye düşen görev idealar dünyasını anlamak ve bu durumun gerçekliğini ispatlamaktır. Nesneler sürekli olarak bir değişimin parçası olarak var olduğundan, duyular dünyası da şeylerin oluş sürecinden yokluğuna tanıklık etmektedir. Platon'da bir yansıma olarak görülen ve hakikatin kendisi olmayan duyu dünyası ve buna bağlı çıkarımlar, idealist düşünme biçiminde Platon'a devrinin öncülleri arasında olmayı sağlamıştır. Platon, kendi dönemindeki 
revizyoncu fikirlerin birçoğundan farklı olarak siyasal hayatı etkilemiştir. Siyasal hayatta var olan kalıpların tekrar gözden geçirilmesiyle ilgilenmeyen Platon; onlara ilişkin olarak, toplumda gerçekleşmesi beklenen amaçlara -üyelerinde erdem ve mutluluk oluşturacak yeni kapasitelerin ortaya çıkması konusunda- ulaşım ve değişim sağlayacak devrim zihniyetiyle ilgilenmiştir. Pekâlâ, böylesi bir dünyanın insana ve doğaya yaklaşımı nasıl gerçekleşir? Toplumun kurgulanmasındaki gerçeklik nedir? İnsan doğasının toplumsal anlayışı siyasal sisteminde ne derecede gerçekleşebilir? Kendi siyasal düşünce sisteminin merkezinde insan olan Platon, fikirlerini oluştururken hocası Sokrates'in düşünce dünyasından etkilenmiştir. Platon'un hocas1 Sokrates, felsefi etkinliklerden söz edebilmek için fikirlerin merkezinde insanın yer alması ve felsefi düşüncenin insanın doğasına yönelik olması gerektiğinin son derece farkındaydı (Senemoğlu, 2016: 44).

Her insan topluluğu bir dünya kurma girişimidir. İnsan düşüncesinin bir ürünü ve bu ürünün haricinde bir şey olmayarak gerçekleşen toplum olgusu; süreklilik sağlayıcı bir tarzda, insana karşı oluşturduğu icra etkisiyle diyalektik bir süreçtir. İnsan ürünü olan toplum, sahip olduğu bütün varlı̆̆ı, insan eylem ve bilincinin kendisine verilmesiyle sağlamaktadır. İnsanın dünyasından başka oluşturulamayan sosyal gerçeklik; toplumun inşasında, insanın yer edinmesi için nesnelleştirilmiş bir dünyayı öne çıkarmaktadır. Kurumların, rollerin ve kimliklerin toplumsallığı nesnel bir şekilde kavraması ve içeriklendirmesi; gerçekliği, bir fenomen olacak şekilde topluma bütün öğeleriyle sunmaktadır (Berger, 2015: 51-67).

Yapısallaşma teorisi, sosyal bilim araştırmalarında dinin ana eksen olarak alındığı toplumsal ve yapısal bakış açılarındaki ayrımlılıkları giderebilir. "İkilik" sürecinde yapı ve aktörler arasında belirlenen ilişki; modern toplumlarda aktör olarak yapının kendisinden soyutlanmayan -dini inancı güçlü- insanların, öncekilerden düşünüş farklılıklarını da anlama imkânı sağlamaktadır (Bodur ve Çapcıoğlu, 2015: 145). Verili olmaktan ziyade "yapılar"ın sınırlı yorumunda- belirsizlik duygusuna ilişkin akılcı hesaplar; görünür yapıdan toplumsal olarak betimlenen konumlara ait söylem ve pratiklerdir. Özsel belirlenemezlik; dünyanın yaşanan anlamını, pragmatik güçlerin istikamet verme yönündeki çoğulluk ve farklılaşımları arasında deneyimlemektedir. $\mathrm{Bu}$ bağlamda Anthony Giddens öğretisi; bilgi, toplumsal sınıf-tabakalaşma, eylemsel aktör olarak birey ve din sosyolojisi ekseninde ortaya konulacak ve değerlendirilecektir. 


\section{Toplumsal Sınıf-Tabakalaşma}

İnsan toplumsal bir varlıktır. Toplumsal sistemlerin üç temel unsurlarından birincisi insanlar, ikincisi gruplar, üçüncüsü ise toplumsal ilişkilerdir. Toplumsal ilişki, insanların toplum halinde örgütlenmelerini ifade eden önemli bir sosyal unsurdur. Durkheim'ın toplumları mekanikorganik dayanışmaya sahip olarak nitelediği ikili kavramlaştırmasında sosyal ilişkilerin niteliği temel ayırt edici bir özellik olarak ortaya çıkmaktadır (Akyüz, 2007: 15). Spencer'a göre toplumsal fenomenlerin ilk iki etkeni kozmik ortamla, bireyin fiziki ve ahlaki yapısıdır. Birincisi toplum üzerinde, yalnızca ikincisinin aracılığıyla etki yapabilir. Böylece bireyin fizik ve ahlak yapısı toplumsal evrimin başlıca itici gücü olmaktadır. Toplum oluşuyorsa, bireye doğasını gerçekleştirme olanağ 1 vermek içindir ve toplumun uğradığı tüm dönüşümlerin tek amacı da bunu daha kolay ve eksiksiz k1lmaktır (Durkheim, 2015: 99). Mutluluğun temel ve evrenselleştirilebilir bir değer konumuna yerleştirilmesi, mutlu olan fakat inisiyatif ve içerikten yoksun halde gün boyunca etrafta amaçsızca dolaşan robotlardan meydana gelen bir toplum oluşturma olasılığını beraberinde getiriyor gibi görünebilmektedir. Güvenlik, kendine saygı, kendini gerçekleştirme ihtiyacı yoksul için olduğu kadar zengin için de kıt olan mallar olarak ortaya çıkmaktadır. Yapıcı bir eşitlik veya eşitleştirme modeli zengin ve yoksul arasında yeni bir anlaşma için uygun koşullar sağlayabilir. Böyle bir anlaşma yaşam tarzı değişikliğine dayalı bir çaba pazarlığı olabilmektedir (Giddens, 2002: 192-194).

Mühleti bitmiş olan feodalizm, faydasız unsurlarıyla birlikte sınıf ve sınıfsal çatışmalar meselesindeki öncelik sağlayan konumunu; kendisinden beklenen sonucu vermeye çalışan endüstriyel sınıfın mücadele alanında bulmuştur. Yeniden tasarlanan toplum, maddi ödüllere dağılım açısından eşitlikçi olmayan bir farklılık getirmiştir. İş bölümünün karşılıklı bağımlılığı, çeşitli gruplar arasındaki ilişkilerde, içeriği bakımından rekabete neden olmaktadır. Bundan dolayı mesleki konumların elde edilmesi, miras yoluyla kazanılmış ayrıcalıklardan daha çok kişisel beceriler ve kapasitelerle belirlenmektedir (Giddens, 1999a: 28). Diyalektik materyalizmin ya da Marksist felsefenin özgün konusu, bilgilerin üretimi, düşünce sürecinin yapısı ve işleyişidir. Daha doğru bir ifadeyle, diyalektik materyalizmin konusu, bilimsel üretim tarihi kuramıdır. Tarihsel materyalizm, diyalektik materyalizmi aynı kuramsal hareket içinde ayrı bir disiplin olarak keşfetmektedir. Çünkü bir tarih biliminin, konusunu tarih kavramının tarihsel materyalizmin kuruluşu olarak tanımlayan bir bilimin oluşması, bir bilim kuramı tanımına yol açmaktadır (Poulantzas, 2014: 9). 
Sınıf ilişsilerinde sosyal tabakalaşmanın yalnızca tek taraflı belirlendiği bir anlayışın varlığını vurgulayan Marx, sınıf olgusunu üretim araçlarının sahipliği yönünden tanımlamaktadır. Zenginliğin ve mülkiyetin dağılımıyla doğrudan ilgilenmeyen Marx, sınıf kimliğinin farkındalığını idrak eden örgütlü grupların dönüşüm süreçlerini "kendisi için sınıf" kavramıla; bu bilincin farkında olmayan proletaryayı ise "kendi içinde sınıf" kavramıyla tanımlamaktadır. Marx'ın kullandığı tanımlamalar, emekçi sınıfın bilinçlenerek kapitalist toplumun dönüştürülmesinin bilincinde olmasını ifade etmektedir. O, kapitalist sınıfı, iki karşıt sınıfın yapısıyla ortaya koyarken; kapitalizm geliştikçe, beyaz yakalı sınıf mensuplarının sayısında artı̧̧ olacağını öngörmektedir. Ancak beyaz yakalı sınıfin muhtemel olarak kapitalist sistemden sosyalist sisteme geçişi sağlayabilecek dinamik bir yapısını görmediğinden bu sınıfin detaylı analizlerine yönelmemiştir. Aylıklı orta sınıfi, ayrıcalıklı zengin sınıfın yardımcısı olarak görmektedir. Aylıklı orta sınıf, büro ve beceriye dayalı hizmet gerçekleştirerek aşırı derecede artık değer üreten kapitalizmin ihtiyaçlarını gidermektedir. Gerçekleştirdikleri işlerle emekçi sınıfa kıyasla aşırı kazanç sağlayabilirler fakat işçi sınıfıyla fazlasıyla ilişkilidirler. Sömürü ilişkisi içinde oldukları kapitalist sınıfa, kazandıkları ücrete göre bağımlılık gösterirler. Statü, insanlardaki sosyal farklılıklardan dolayı ortaya çıkarken; sınıf ise objektif şekilde verilidir. Mülkiyet ve kazançtan kaynaklanan iktisadi faktörler sınıfları meydana getirirler. Gruplar hayat biçimleriyle statüleri belirler. "Diğer sosyal gruplara göre konumlarını alt ya da üst derecelerde kavrayan insanların toplamı; kendilerinde eşit biçimleri, benzer değerlerdeki varlıkları görebilen statü gruplarıdır" (Aydın, 2018: 251-255).

Saint-Simon geleneğine bağlı kalan Durkheim, endüstriyalizm etkisinde toplumsal kurumların doğasıyla ilgilenmiştir. Durkheim, kapitalizmdeki rekabetin endüstriyel düzenle birlikte merkezileşen somut özelliğini vurgulamıştır. Durkheim'ın kısa ve belli bir süre için değerlendirdiği kapitalizmin bazı özelliklerine Marx aşırı derecede önem vermiştir. Anlaşılması güç bağımlılık ilişkilerinin canlandırıcılık etkisi, doğadaki üretimin sanayi hedefli kullanımıyla gerçekleşirken; modern hayatın toplum yapısının ayırt edici niteliği, kapitalizmin karakterinden kaynaklanmaktadır. Weber'de nitelendirilerek ortaya konulan "rasyonel kapitalizm" emeği metalaştıran ve Marx'ın belirlediği iktisadi mekanizmaları kapsayan bir ifadedir (Giddens, 1998: 20).

Toplumsal tabakalaşma yaklaşımlarında Durkheim-Weber karşılaştırması yapıldığında her iki yazarın da yaptıkları çalışmalarda az sayıdaki benzerliklerden hareket edilebilmektedir. Weber, güç ve iktidar kavramıyla toplumsal eşitsizliklere dikkat çekmektedir. Toplumsal 
eşitsizliğin oluşmasında etkili olan siyasal, dinsel ve kültürel güç kaynakları hassas konumlarını korurken; Weber'e göre modern toplumun gücü yalnızca üretim araçları ve mülkiyete dayalı olarak sağlanmamaktadır. Bundan dolayı Durkheim, değişik konumlara sahip güç merkezlerinin olduğunu ve modern toplumdaki güç olgusunun yalnızca sınırlı bir azınlıkta toplanmadığını ileri sürmektedir. Bir başka benzerliği Durkheim tarafından incelenen meslek gruplarında oluşan güç merkezi olarak modern toplumun birey-devlet arasındaki yapısında görmekteyiz. Durkheim ve Weber devlet konusuna önem veren sosyologlardır. Durkheim'a göre devleti yönetenler olumlu özellikleriyle ön plana çıkarken; Weber'in düşüncesinde ise devlet yöneticileri bask1 yoluyla devletin imkânlarını şahsi yararları adına kullanarak başkalarını tahakküm altında tutabilmektedirler. Durkheim'a göre güç mücadelesinde toplumsal hayatı şekillendiren merkezi konum önemli değildir. Güç olgusunun kötü yorumlanmasında, toplumsal dayanışmanın eksikliği ve ahlak öğelerinden kaynaklanan sarsıntılar etkili olduğundan; bu durum Durkheim için sınıf çatışmasını belirgin hale getirmektedir (Aydın, 2014: 221).

Dahrendorf'un yaptığı analizde ise bir sanayi toplumu farklılaşmış sayılardaki çatışmaların ve ittifakların birlikte yaşandığ 1 yoğun bir toplumdur. Sanayi toplumlarının kuruluşunda, farklı sınıflar arasındaki refah ve etki potansiyellerinin farklılığı eşitlikten uzaklaşılmasına neden olmaktadır. Sanayi toplumlarında, eğitimin bireylerde oluşturduğu sistemsel başarılar veya başarısızlıklar toplumsal konumları belirleyen bir ölçüt haline gelmektedir. Toplumsal hareketlilik sanayi toplumlarının yapısının hayati unsurlarından birisi haline gelmiştir. Sanayi toplumunda kapitalizm, günümüzde toplumsal düzenin bireylerin istek ve iradesi dışında üstünlük kazandığı bir form haline gelmesidir (Giddens, 2016: 38-39). Kapitalizmin doğuşu üzerine argümanında Sombart, ihtiyaçların giderilmesiyle kazanç elde etmeyi ekonomi tarihindeki iki büyük başlıca ilke olarak birbirinden ayırmıştır (Weber, 2017: 59).

Siyasal eşitlikte "özgür bireyler" asıl olarak onayladıkları "toplumsal sözleşme"yle sosyal modelleri oluştururken; ulus devlet tarafindan feodal dönemde geçerli olan ataerkil, hiyerarşik dinsel kurumlar dışlanarak vatandaşlığı sağlayan sembol değerlere ulaşılmıştır. Kamusal alanda oluşan "özgürleştirici" yasal eşitlik ilkesiyle vatandaşlık; kapitalizmde, feodalizme göre bireylerde ilerlemeci bir anlayış geliştirmiştir. Fakat kapitalizmde oluşturulan sivil toplum-devlet ayrışmasıyla siyasal alanekonomik alan ayrışmasında siyasal alan, yasal eşitlik ilkesinde gerçekleşmektedir. Yasal eşitlik sadece siyasal/kamusal sahada kurgulanarak ekonomik sistemle siyasal sistemin değişmez şekilde 
ayrıştıılmasına; sivil-ekonomik sahada sınıf, katmanlaşma, kimlik ve sosyal eşitlik üzerinde belirsizliklere ve aynca eşitsizliklere kaynak teşkil edebilmektedir (Güllüpınar, 2012: 91).

Küresel çağda devlet, siyaset bilimcilerin "çok katmanlı yönetişim" dedikleri unsur içerisinde faaliyet yürüterek (Giddens, 2013a: 16) küreselleşme olgusuyla birlikte yaşamlarımızın kültürel, ekonomik, siyasi, insan hakları yönlerini etkilemektedir. Aile değerlerinin içinde bulunduğu durumla alakalı tartışmaların merkezinde küresel etkiler yönlendirici olmaktadır. Bunların dışında, kadınların gün geçtikçe artan eşitlikçi taleplerinin etkisiyle geleneğe dayanan aile sistemlerinin dünyanın çeşitli bölgelerinde değişime zorlandığı görülmektedir. Birbirlerine karşıt ya da çelişik faktörlerin devrede olduğu bir hareketler bütünü olarak küreselleşme (Giddens, 2000a: 24-25), dünyadaki olguları etkileyen bir anlayış ve algılama biçimi oluşturarak, insanlarda ve toplumlarda bir olma durumunda etkileşim sağlamaktadır. Bunların etkisiyle küreselleşmenin insanların ve toplumların bilincinde farkındalık yoluyla yoğunluk kazanması, dünyanın küçülmesine göndermede bulunmasina sebep olmaktadır (Kula, 2005: 10).

Kişisel hayatın demokratikleştirilmesi ile en geniş düzeyde global politik düzendeki demokratik olanaklar arasında bir simetri mevcuttur. Mahremiyetin bulunmadığı bir kişisel ilişkiyle eşitlenebilen bir konumsal pazarlıkta iki taraf da ilişkiye aşırı bir konum alarak yaklaşmaktadır. Karşıllklı tehditler ve sürtüşmeyle bir taraf yıpranır ve eğer müzakere süreci o zamana kadar kesilmediyse sonuç gerçekleştirilir (Giddens, 2010: 179).

\section{Anthony Giddens'ta Toplumsal Yapılaşma}

Durkheim'a göre, sosyoloji dahil bütün bilimler ancak yavaş yavaş ve ihtiyatlı bir biçimde toplumsal olgularda gözlemlenen düzenlilikler temelinde yapılan sabırlı tümevarımsal genellemeler yoluyla ilerlemektedir. Durkheim, toplumun bilimsel incelemesinin normal olanı patolojik olandan ayırma aracını verebileceğini iddia ederken, Comte'un pozitivizm programının esas kısmını onaylamaktadır. Çünkü sosyoloji ilerici bütün toplumsal değişimlerin sadece birikim yoluyla gerçekleştiğini göstermektedir (Giddens, 2000b: 154-155).

Weber, nesnellik üzerine yazısında, sosyal bilimlerde zihinsel olgularla, doğası gereği genelde kesin doğa bilimlerindeki şemaların çözebileceği veya çözmeye çalışabileceği türdekinden, özellikle farklı bir görev olan empatik 'anlama'yla ilgilendiğimizi vurgulamaktadır. $\mathrm{Bu}$ yüzden toplumsal olguların analizinde temel adımlardan biri, onun öznel temelini 
anlamaktır (Giddens, 2009: 236). Toplumun sıradan üyelerinin zihnindeki 'bağlantılar' gündelik toplumsal hayatın pratik yükümlülükleriyle uyumludur; fakat sosyolog gözlemcilerde bu durum salt bilişsel veya teoriktir. Schutz'a göre, yorumcu sosyolojik yöntemin amacı, eylemin öznel temellerini aydınlatmak için tipik davranış biçimleri hakkında teorik modeller inşa etmektir (Giddens, 2013b: 50).

Giddens'a göre sosyoloji; sosyal dünyayı gerçeklik doğasıyla incelemekten daha çok elverişli bilginin üretilmesi problemiyle, toplumun hangi yolla bilinebileceği sorularıyla ilgilenmektedir. Gerçekliğe ilişkin anlayışımız, dilin aracılığında şekillendiğinden, gerçekliğe ait konumumuz önemli kriterlerde bir anlam sorunudur. Bundan dolayı gerçeklik, belli koşullarda anlaşılabilecek epistemolojiyle ilgili bir sorun olduğundan ontolojik çalışmalara odaklanmamız gerekmektedir. Değişik toplumsal kuram ve sosyolojik okumaların varlıkla ya da oluşla ilgili konuları inceleme yöntemlerini ve toplumun oluşmasında etkili olan şeylerin araştırılmasını tavsiye etmektedir (Tatlican, 2005: 2-3).

Yapılaşma kuramıyla (structuration theory) Giddens, Uluslararası İlişkiler alanında yapılan çalışmalara sağladığı katkılarla bilinmektedir. Giddens, yapılaşma kuramını oluştururken üç önemli eserinden yararlanmıştır. Bu eserler sırasına göre; Sosyolojik Yöntemin Yeni Kuralları, Sosyal Teorinin Temel Problemleri ve Toplumun Kuruluşu başlıklarıyla yayınlanmıştır. Giddens, kitaplarındaki değişiklik gösteren ve yenilenmiş içerikleriyle yapılaşma kuramına aşama aşama ulaşmıştır. Giddens kuramında aktör-yap1 ve özne-nesne ayrımlarının ve karşıtlıklarının geçerli olmadığı yolundaki iddiasını dile getirmektedir. Yapılaşma kuramıyla Giddens, güncel bir sosyal kuram oluşturmak adına aktör eylemlerini ve bununla birlikte yapı kurallarını ve kaynaklarını etki unsuru olarak değerlendirmiştir. Böylelikle yapı, fail, özne, nesne kavramsallaştırmalarına esaslı yenilikler getiren yapılaşma kuramıyla sosyal bilimler alanında etkisini gösteren bağlamların kullanılabilmesindeki imkânlar artmıştır. Tam anlamıyla özneye önem verilmeyen ya da öznesizliğin belirlediği yapısalcı yaklaşım yanında, rasyonel aktör eylemlerini yapıya göre öne çıkaran yaklaşımlardan farklı olarak, Giddens üzerinde düşünülmesi gereken sosyolojik ve teorik bir kavramsallaştırma oluşturmuştur. Bu çerçevede yapılaşma kuramındaki sınırları keşfedebilmek için kilit önemdeki kavramlar sistem, yapı ve yapının ikiliği olarak karşımıza çıkmaktadır (Emre, 2015: 6-7).

Giddens, toplumsal yaşamın yinelemeli karakterine -gündelik toplumsal eylemde bu eylemin yapısal momentinin, onları inşa eden kaynaklardan çıkan yapının ikiliğiyle sürekli olarak nasıl yaratıldığına- ilgi 
duymaktadır. Aktörler eylerken, gerçekleştirdikleri eylemler aracılığıyla, kendilerine eyleyebilme imkânı sunan şartları yeniden üretirler (Richter, 2017: 105). Buna ek olarak yapılaşma süreciyle birlikte toplum; insan eylemleriyle biçimlenerek, yapıyla ilgili belirleyiciler aracılığıyla üretilmektedir. $\mathrm{Bu}$ biçimdeki yapılaşma teorisiyle, birey ve toplum ikiliğinin reddi sağlanarak (Saygın, 2016: 71) sosyal sistemlerdeki fail ve yapının birbirlerine bağımlılı̆̆ı vurgulanmıştır (Toker, 2005: 13).

Giddens'a göre yapı, insanın faaliyetlerinde gerçekleşen bir akış sağlayarak öznelliği sadece bireyde içkinleşen bir fikir olarak ele almakta ve asıl farkındalık ilişkisinde nitelik kazanmaktadır (Giddens ve Pierson, 2001: 60). Topluma ilişkin tekrarlayan üretim zaman-uzam düzleminde sergilenerek yapının ikiliğindeki süreklilik sağlanmaktadır. Eylem akış durumu sona ermedikçe, insan bilgisinin sinırlllı̆̆ında istenmeyen sonuçların çıkması kaçınılmazdır. İstenmeyen sonuçların olumsuzlukları da geri beslemede farkına varılamayan eylemlerin koşullarını oluşturmasıdır (1999b: 71). Sosyolojik düşüncede zaman kavramına gerekli değerin verilmeyişini sorgulayan Giddens, bu nedenle sosyolojideki en önemli yaklaşımlardan ikisini -işlevselcilik -yapısalcılık eleştirmektedir. Giddens, işlevselciliğin ve yapısalcıllığın zaman-uzam kesişmeleri, eş zamanlı/art zamanlı ayrımı yapılan zaman boyutuyla toplumsal kuramı etkilediğini düşünmektedir (Okumuş, 2010: 169).

\section{Anthony Giddens'ta Din Sosyolojisi}

Bauman'a göre din, insanın tanımlamak istediği zamana kadar tam olarak anladığı ilginç ve çoğunlukla sıkıntı verici kavramlar ailesine girmektedir. Postmodern akıl, modernize bilime dayanan aklın dışladığı ve sınır ötesine çıarılan bu aileye daimi bir oturma izni vermiş konumdadır. Dünyanın değişmez sınıfları içermesi ya da keskinleşmiş bölümlerle dağıtılması hayali postmodernist akılda, modernist karşıtlarına heyecansız gelmektedir (2013: 244-248). Geleneksel pozitivistik görüş̧te din, belli akıl dışı inançların kurumsal karışımıdır. Bunların, bireylerin ve toplumların bilişsel ancak üstesinden gelinebilir bir gerçeklikle karşılaşmalarından kaynaklandığı farz edilmektedir. Özgün pozitivistik konumun, dinin beşeri aklın evrimindeki ilkel bir aşama olarak en sonunda yerini bilime bırakacağ 1 tezini içerdiği iyi bilinmektedir (Luckmann, 2016: 71).

Dinlerin hiçbiri yalnızca bireylerde içselleşen öznel bir deneyim şeklinde kalmamakta tersine somutlaşarak ya da bir davranış biçimine evrilerek nesnelleşmektedir. Dinsel düşüncelerin, duyguların ve heyecanların ifadesiyle birlikte din-toplum ilişkisindeki etkileşim bir karşıllğa dönüşerek, dinsel yönden, anlamsal bir diyalektik süreç ortaya 
çıkmaktadır. Kişiler arasındaki etkileşimin anlamlı hale gelebilmesi benzer deneyimlerin hareketler, sözler ya da fiillerle nesnelleşerek ifade edilmesine bağlıdır (Akyüz ve Çapcıoğlu, 2015: 43). Dinlerin tümü de kendilerine inanmış toplulukların ifa ettiği ayinleri ve yüceltilmiş duyguları da kapsayan simgeler kümesi olarak bilinmektedir. Dine yapılan toplumsal yaklaşımlarda yoğun olarak klasik düşünürlerden Marx, Durkheim ve Weber'in düşünceleri etkili olmaktadır. Her üç düşünür de din tarafindan yaratılan "diğer" dünyaya ait değerlerin, asıl düşüncelerde bir yanılsamaya neden olarak, dinsel simge lensleri vasıtasıyla dünyamızın çarpıtıldığını kabul etmişlerdir (Giddens, 2012: 626).

Aydınlanma düşüncesinin evrensel niteliğiyle ilgili anlatının Avrupa'nın sömürgeci yayılmasına rastlaması ve bu süreçte muktedir hale gelmesi büyük önem taşımaktadır. Aydınlanma filozofları tarafından inceden inceye ele alınan toplumsal ve entelektüel ilerleme görüşü, emperyalist hırslar doğrultusunda ideolojik bir meşrulaştırma sağlamıştır. Akılcı aydınlanma ilkelerini ve kurtarılmış bireyselliği benimseyen dini çalışmalar, sömürgeci projenin kendi değerlerini yansıtmak ve siyasetini uygulamak suretiyle daha geniş siyasi topoğrafyaya karışmıştır (Hawthorne, 2012: 228-229). Kutsalın özselleştirilerek dışsal, aşkın bir güç haline getirilmesini kolaylaştıran din ve doğanın evrensel kategoriler halinde inşa edildiği aydınlanmış mekânda ve zamanda kutsallığa dair teorileştirmeler etkili olmaktadır. Akıl, yalan şeylerin ya yasaklanmasını ve ortadan kaldırılmasını ya da doğru dürüst eğitilmiş duyular tarafından görülecek, işitilecek ve dokunulacak nesneler olarak kaydedilip yeniden konumlandırılmasını gerektirmektedir. Evrensel akıl sahte gücün maskesini başarıyla düşürerek kendi konumunu meşru güç olarak sergilemektedir. Böylece kiliseye ait mülkler ve ortak topraklar tahliye edildikten sonra kutsal mülkiyet hakkı evrensel bir hal almıştır (Asad, 2016: 49-50).

Hristiyanlığın bazı dini eğilim şekilleri ve ahlaki kavramlarının kabulü çok sayıda Avrupalı arasında, hatta kilisenin Ortodoks kurumunun yer edinemediği bir kesimde bile geniş ölçüde devam etmektedir (Davie, 2005: 10). Dinin modern baskılara kurban edilişi, birtakım klasik sosyoloji tariflerinde baskın biçimlerde kendisini göstermiştir. Dinin hem marjinalleşeceği hem de etkisizleşerek gücünü kaybedeceği anlayış1 sekülerleşmenin birincil dinamiği olmuştur. Tam aksine dinin postmodern okumalar içindeki sosyalleşme durumu geçmişe göre daha da artmaktadır. Anthony Giddens'a göre bu durum dinsel öğretilerin görünmez olmadığının ve tekrar canlanarak toplumsal hayatta yaşadığının ispatıdır (Lyon, 2011: 211). Bu çerçevede Giddens, dine yorum getiren 
birçok çağdaş sosyoloğun da Batı'da bir kilise veya tapınak üyesi olarak faaliyet gösterdiğini belirtmektedir (Kurt, 2008: 85).

Geleneksel toplumları incelerken Giddens, dini kozmolojileri inanç ve ritüel uygulamalarının bir şekli olarak güven çerçevesinde ele almaktadır. Bunun nedeni, dini kozmolojilerin kişisel ve toplumsal yaşama ve doğaya ilişkin ahlaki ve uygulamayla ilgili açıklamalar getirmesidir. Din, geleneksel toplumlarda risk ortamlarında da bir rol oynamaktadır. O, bir endişe kaynağı olabilirdi; çünkü doğanın tehlikelerine ilişkin tehditler, genellikle dinsel kodlar ve semboller aracılığıyla tecrübe ediliyordu. Modern toplumları incelerken Giddens, modern yaşamdaki çoğu durumun, günlük yaşama nüfuz eden bir güç olarak dine uygun olmadığını vurgulamaktadır. Modern toplumlarda dini kozmoloji yerini maddi teknolojiye odaklı mantıksal düşünce ve deneysel gözlem tarafindan yönetilen bilgiye bırakmaktadır.

Giddens'a göre din ve gelenek birbiriyle yakından ilişkilidir. Giddens, modern yaşamın her ikisini de zayıflattı̆̆ına inanmaktadır. Bununla birlikte gelenek dinden çok daha fazla zayıflamaktadır. Giddens, yüksek modernitenin yeni ahlaki sorunlar ürettiğini iddia etmektedir. Dine yönelik ilginin yeniden dirilişi, doğum, evlilik ve ölüm gibi önemli yaşam olayları sırasında gerçekleşmektedir. Giddens, yüksek modernitenin son sınırına ulaştığını, bu yüzden de dinin günümüzde kendini sahne merkezine geri dönmeye zorladığını savunmaktadır (Furseth ve Repstad, 2013: 130-131). $\quad \mathrm{Bu}$ şekilde, dinin varlığını sürdürmesi yüksek modernitenin bir sonucudur. Giddens dini, bireysel tepkilerin moral açmazlara olan etkisinde incelemektedir. Giddens, kolektif yönlerin hesaba katılmadığı; bireyselleşen ve rasyonelleşen, sınırlı bir din profili ortaya koymaktadır (Bodur ve Çapcıoğlu, 2015: 145).

Din toplumda varlığını giderek daha fazla hissettirdikçe din sosyolojisinin önemi de giderek artmaktadır. Dini şuurun yükselişi veya kutsalın geri gelişi bugün artık evrensel bir olgudur. Bilimin, teknolojinin ve modernizmin yayılıp gelişmesiyle ortadan kalkacağ giderek artan sosyal rolü dünyanın hiçbir yerinde inkâr edilememektedir (Şentürk, 2017: 156). Sekülerleşmeyle birlikte dinlerin kamusal alanda güçlenip, direnç kazanma yolundaki öncelikli çabaları; toplumsalın modernleşen dünyasında, bu çabaların sonucunda kamuyla ilgili alanlardaki imkânlardan faydalanma isteklerini beraberinde getirmiştir (Çiğdem, 2004: 507).

Tarih, insanlığın kendisiyle ve gerçeklikle ilgili tecrübelerinin kayıtlarını temin etmektedir. Bu kayıtlar aşkınlığa ait işaretler olarak adlandırılan tecrübelerin çeşitli biçimlerini içermektedir. Teolojik teşebbüs, her 
şeyden önce bu tecrübelerin çeşitli formlarını da içermektedir. Hakikatler keşfedilebilir ya da kaybolabilir. Tarih, ne içindeki tüm kedilerin gri olduğu bir gece ne de bizi durmakta olduğumuz noktaya çıkaran dev bir asansördür. Hakikatle ilişkili her bir iddiaya, 19. yüzyıl tarihçisi Ranke'nin deyişiyle "Tanrıya yakınlık" içinde ve aynı anda toplumsaltarihsel konumun varlığından daimi şekilde haberdar olarak kendi çerçevesi içinde bakılmalıdır (Berger, 2012: 113-125).

\section{Sonuç}

Siyasal dille ilgili tartışmalar ve deneyimler, yaşadığımız dünyada, gündelik hayatın fenomenlerini bir iletişim aracı olarak kullanmaktadır. Modern toplumun yapılanmasında bilgi, yeni sistemlerde yönetsel iktidarla birlikte uzam ve zaman kesitinde bir değişim süreci başlatmaktadır. Dilin kendisini tekrarlama özelliği -toplumsal uygulamalarda- bireyin yapısal alışkanlıklarını etkilemektedir. Yapının görünürlüğü, insanların yaptıkları şeylerin gerçekliğindeki üretim istikrarındadır. Bireysel hayat alanı, otonomiyi, düşünümsel benliğin projelerinde gerçekleştirmektedir. Düşünümsel benlik ise başkalarının psikolojik eğilimlerindeki özgürleştirici idealleri güç eşitliğinin sağlanmasıyla geliştirebilmektedir.

Yap1 kavramı toplumsallaşmanın var olan fiziksel gerçekliğinde değişkenlik gösteren bilişsel bir eyleyene bağlıdır. İnsan öznelliğindeki nesneler dünyası, failin etkinliklerinde; eylem kavramını, davranış zamansallığında soyutlamaktadır. Yapının ikiliği, eyleyenlerin etkinliklerindeki sistematik bağlamları bilinç düzeyine taşımaktadır. Fail ise toplumun rasyonel biçimlerinde benimsediği eylemlerini, ahlaki olarak kendisinde bütünleştiren mekanizmalarda karakterize etmektedir.

Yapılaşma kuramı, öznel deneyimi; insan etkinliğinin neden-sonuç ilişkilerinde kavranabilen maddi dünyada yorumlamaktadır. Öznellik ve anlam kavramlarıyla -yapılaşma kuramında- uzam ve zaman süresince tekrarlanan sosyal pratikler ortaya çıkmaktadır. Eylem, edimlerin ussallaştırılmasında -normatif eğilimleri yönlendiren- olgusallıklar içermektedir. Eyleyebilmek; insan eyleyenlerini farklılaştıran, düşüngüsel süreçleri olanaklı kılmaktadır.

Giddens, dini inançla ilgili kodların ve sembollerin modern hayattaki anlaşılamayan sonuçlarına vurgu yapmaktadır. Dini, sosyal toplumlardaki varoluşsal uygulamaların karakteristik özellikleriyle tartışmaktadır. Bireysel eylemlerin yapının kolektif yorumunda düşünülmesi, dine uygunluğun mantıklı çıkarımlarında gerçekleşmektedir. Dini duyarlılıkların bireyin kimlik üzerindeki kendisini dönüştürme çabalarını 
anlamlı kılmadığını savunmaktadır. Ayrıca Giddens, dini canlanmaları bireylerin yaşadıkları toplumsal çelişkilerin usa vurumuna bir yanıt olarak düşünmektedir.

\section{Kaynaklar}

Akyüz, N. (2007), Dinin Örgütsel İklimi: Dini Gruplar, Ankara: Gündüz Eğitim ve Yayıncılık.

Akyüz, N. ve Çapcioğlu, İ. (2015), Din ve Toplum İlişkileri, Edit. Niyazi Akyüz ve İhsan Çapcığlu, Din Sosyolojisi El Kitabı, 3.Bask1, Ankara: Grafiker Yayınları, s.43-47.

Apal1, Y. (2015), Bilgi Sosyolojisi Açısından Din ve Zihniyet, Nevşehir Hacı Bektaş Veli Üniversitesi SBE Dergisi, 5(1), s.189-213.

Asad, T. (2016), Sekülerliğin Biçimleri: Hıristiyanlık, İslamiyet ve Modernlik, Çev. Ferit Burak Aydar, 2.Bask1, İstanbul: Metis Yayınları.

Aydın, K. (2014), Yapısal İşlevselci Teori ve Toplumsal Tabakalaşma, Yalova Sosyal Bilimler Dergisi, 5(8), s.213-239.

Aydin, K. (2018), Max Weber, Eşitsizlik ve Toplumsal Tabakalaşma, Journal of Economy Culture and Society, 0(57), s.245-267.

Bauman, Z. (2013), Postmodernizm ve Hoşnutsuzlukları. Çev. İsmail Türkmen, 2. Baskı, İstanbul: Ayrıntı Yayınları.

Berger, P. L. (2012), Melekler Hakkında Söylenti: Modern Toplumda Tabiatüstünün Yeniden Keşfi, Çev. Ali Çoşkun ve Nebile Özmen, İstanbul: Rağbet Yayınları.

Berger, P. L. (2015), Kutsal Şemsiye: Dinin Sosyolojik Teorisinin Ana Unsurları, Çev. Ali Coşkun, 5.Baskı, İstanbul: Rağbet Yayınları.

Berger, P. L. ve Luckmann, T. (2003), Bilgi Sosyolojisi ve Sosyolojik Teori, Çev. Ejder Okumuş, Sosyal Bilimler Araştırma Dergisi (SBArD), 1(2), s.299-302.

Bodur, H. E. ve Çapcıoğlu, İ. (2015), Sosyolojik Teori ve Din, Edit. Niyazi Akyüz ve İhsan Çapcıŏlu, Din Sosyolojisi El Kitabl, 3.Bask1, Ankara: Grafiker Yayınları, s.111-147.

Çelebi, V. (2014), Nicolai Hartmann'ın Yeni Ontolojisinde Varlık ve Değer İlişkisi, ETHOS: Felsefe ve Toplumsal Bilimlerde Diyaloglar, 7(2), s.74-97. 
Çiğdem, A. (2004), Kamusal Alan, Kamusal Din ve Kamusal Akıl, Edit. Meral Özbek, Kamusal Alan, 1.Bask1, İstanbul: Hil Yayın, s.501514.

Dağ, M. (1979), Ontolojik Delil ve Çıkmazları, Ankara Üniversitesi Ilahiyat Fakültesi Dergisi, 23(0), s.287-318.

Davie, G. (2005), Modern Avrupa'da Din, Çev. Akif Demirci, 1.Baskı, İstanbul: Küre Yayınlar1.

Durkheim, Ê. (2015), Sosyolojik Yöntemin Kuralları, Çev. Cemal Bâli Akal, 4.Baskı, Ankara: Dost Kitabevi.

Emre, Y. (2015), Anthony Giddens ve Uluslararası İlişkiler: Yapılanma, Modernite ve Küreselleşme, Uluslararası İlişkiler, 11(44), s.5-23.

Furseth, I. ve Repstad, P. (2013), Din Sosyolojisine Giriş: Klasik ve Çăgdaş Kuramlar, Çev. İhsan Çapcıoğlu ve Halil Aydınalp, 2.Baskı, Ankara: Birleşik Yayınevi.

Giddens, A. (1998), Modernliğin Sonuçları. Çev. Ersin Kuşdil, 2. Baskı, İstanbul: Ayrıntı Yayınları.

Giddens, A. (1999a), Ileri Toplumların Sinıf Yapısı: Marks'ın Sinıflar Teorisi, Sonraki Teoriler ve Eleştirel Değerlendirmeler, Çev. Ömer Baldık, İstanbul: Birey Yayıncılık.

Giddens, A. (1999b), Toplumun Kuruluşu: Yapılaşma Kuramının Ana Hatları, Çev. Hüseyin Özel, 1.Bask1, Ankara: Bilim ve Sanat Yayınları.

Giddens, A. (2000a), Elimizden Kaçıp Giden Dünya, Çev. Osman Akınhay, 1.Bask1, İstanbul: Alfa Yayınları.

Giddens, A. (2000b), Siyaset, Sosyoloji ve Toplumsal Teori: Toplumsal Düşüncenin Klasik ve Çağdaş Temsilcileriyle Hesaplaşmalar, Çev. Tuncay Birkan, 1.Baskı, İstanbul: Metis Yayınları.

Giddens, A. (2002), Să̆ ve Solun Ötesinde: Radikal Politikaların Geleceği, Çev. Müge Sözen ve Sabir Yücesoy, 1.Baskı, İstanbul: Metis Yayınları.

Giddens, A. (2009), Kapitalizm ve Modern Sosyal Teori: Marx, Durkheim ve Max Weber'in Çalışmalarının Bir Analizi, Çev. Ümit Tatlıcan, 1.Baskı, İstanbul: İletişim Yayınları.

Giddens, A. (2010), Mahremiyetin Dönüşümü, Çev. İdris Şahin, 2.Bask1, İstanbul: Ayrıntı Yayınları. 
Giddens, A. (2012), Sosyoloji, Edit. Cemal Güzel, 1.Bask1, İstanbul: Kirmız1 Yayınlar1.

Giddens, A. (2013a), Iklim Değişikliği Siyaseti, Edit. Gülben Salman, 1.Bask1, Ankara: Phoenix Yayınevi.

Giddens, A. (2013b), Sosyolojik Yöntemin Yeni Kurallarl: Yorumcu Sosyolojilerin Pozitif Bir Eleştirisi, Çev. Ümit Tatlıcan ve Bekir Balkız, 2.Baskı, Ankara: Sentez Yayıncılık.

Giddens, A. (2016), Sosyoloji: Kısa Fakat Eleştirel Bir Giriş, Çev. Ülgen Y1ld1z Battal, 6.Bask1, Ankara: Siyasal Kitabevi.

Giddens, A. ve Pierson, C. (2001), Anthony Giddens'la Söyleşiler: Modernliği Anlamlandırmak, Çev. Serhat Uyurkulak ve Murat Sağlam, 1.Baskı, İstanbul: Alfa Yayınları.

Göçmen, D. (2009), Neden Ontoloji?, https://dogangocmen.files. wordpress.com/2009/08/neden-ontoloji1.pdf, s.1-4, (Erişim Tarihi: 30.05.2019).

Güllüpınar, F. (2012), Eşitsizlik ve Toplumsal Tabakalaşma Açısından Vatandaşlık Üzerine Sosyolojik Bir Analiz, Ankara Üniversitesi SBF Dergisi, 67(1), s.81-109.

Hawthorne, S. (2012), Din ve Toplumsal Cinsiyet (Çev. İhsan Toker),Der. Peter B. Clarke, Çev. Edit. İhsan Çapcioğlu, Din Sosyolojisi: Kuram ve Yöntem. 1.Bask1, Ankara: İmge Kitabevi, s.223-249.

Kılıç, S. (2014), Heidegger'in Fundamental Ontolojisinde Varlığın Özdeşliği, Kaygl, Uludă̆ Üniversitesi Fen-Edebiyat Fakültesi Felsefe Dergisi, 2014(23), s.11-28.

Kula, M. N. (2005), Küreselleşme, Ruh Sağlığı ve Din. Dinbilimleri Akademik Araştırma Dergisi, 5(2), s.7-30.

Kurt, A. (2008), Sosyolojik Din Tanımları ve Dine Teolojik Bakış Sorunu, Uludă̆ Üniversitesi İlâhiyat Fakültesi Dergisi, 17(2), s.73-93.

Luckmann, T. (2016), Görünmeyen Din: Modern Toplumda Din Sorunu, Çev. Ali Coşkun, Fuat Aydın ve Osman Coşkun, 2. Baskı, İstanbul: Rağbet Yayınları.

Lyon, D. (2011), Din ve Postmodern: Eski Problemler, Yeni İhtimaller, Çev. Mustafa Tekin, Bilimname, 2011(1), s.209-227. 
Nutku, U. (2006), Felsefenin Temel Disiplini: Ontoloji, Felsefe ve Sosyal Bilimler Dergisi, 2006(1), s.79-84.

Okumuş, E. (2010), Zaman Sosyolojisi: Bir Giriş Denemesi, Din Bilimleri Akademik Araştırma Dergisi, 10(2), s.121-174.

Poulantzas, N. (2014), Siyasal İktidar ve Toplumsal Sinıflar, Çev. Şule Ünsald1, 1.Bask1, Ankara: Epos Yayınları.

Richter, R. (2017), Sosyolojik Paradigmalar: Klasik ve Modern Sosyoloji Anlayışlarına Giriş, Çev. Necmettin Doğan, 3.Baskı, İstanbul: Küre Yayınları.

Saygın, A. U. (2016), Anthony Giddens'ın Sosyolojisinde Modernliğin Boyutları, Abant Kültürel Araştırmalar Dergisi (AKAR), 1(2), s.6980.

Senemoğlu, O. (2016), Antik Yunan Siyasal Düşünüşünde İnsan Doğas1 ve Toplum Anlayış1: Platon ve Aristoteles, Insan ve İnsan Bilim Kültür Sanat ve Düşünce Dergisi, 3(10), s.42-63.

Şentürk, R. (2017), Yeni Din Sosyolojileri: Batı'da 1960 Sonrası Arayışlar, 2.Baskı, İstanbul: İz Yayıncılık.

Tatlıcan, Ü. (2005), Sosyal Teoride Düalizmler: Bazı Temel Sosyal Teori Okullarıyla Eleştirel Karşılaşmalar, Anthony Giddens, Sosyal Teorinin Temel Problemleri: Sosyal Analizde Eylem, Yapl ve Çelişki, Çev. Ümit Tatlıcan, 1.Baskı, İstanbul: Paradigma Yayıncılık, s.2-4.

Toker, İ. (2005), Bir Yapılaşma İlişkisi Olarak Kadınlar ve Din-Başkent Kadın Platformu Örnek-Olayl- (Yayımlanmamış Doktora Tezi), Ankara Üniversitesi, Sosyal Bilimler Enstitüsü, Felsefe ve Din Bilimleri (Din Sosyolojisi) Anabilim Dal1, Ankara.

Varol, A. (2010), Bilgi Toplumunda Kamusal Alan, Sosyal Bilimler Dergisi, (4), s.121-129.

Weber, M. (2017), Protestan Ahlakı ve Kapitalizmin Ruhu, Çev. Gökhan Rızaoğlu, 3.Baskı, İstanbul: Oda Yayınları.

Yılmaz, B. (1996), Bilgi Sosyolojisi: Kütüphanecilik Kuramı İçin Bir Deneme, Türk Kütüphaneciliği, 10(1), s.8-20.

Yılmaz, B. (2009), Gerçekliğin Toplumsal İnşasında Bilgi ve Bilgi Merkezi, Bilgi Dünyası, 10(1), s.28-45. 